\title{
Study of Longkou Oil Shale Pyrolysis Behavior with Bitumen as the Intermediate
}

\author{
Jian Shi ${ }^{1, a}$, Yue Ma ${ }^{1, b}$, Jili Hou ${ }^{1, c}$, Shuyuan $\mathrm{Li}^{1, \mathrm{~d}, *}$, Jinsheng Teng ${ }^{2, \mathrm{e}}$ \\ ${ }^{1}$ China University of Petroleum, Beijing 102249, China; \\ ${ }^{2}$ Shandong Energy Longkou Mining Group CO., LTD, Longkou 265700, China \\ a403643995@qq.com, bmayue198417@163.com, 'www.houjili@126.com, \\ dsyli@cup.edu.cn, elkjttjs@126.com
}

Keywords: Bitumen, oil shale, intermediate, pyrolysis.

\begin{abstract}
Oil shale as the petroleum alternative is widely distributed in China, the total oil shale resources and potential shale oil resources are estimated at 719.937 billion tons and 47.644 billion tons, respectively. Shale oil and gas can be obtained through the pyrolosis of the oil shale. In order to study of the behavior of the pyrolosis of Longkou oil shale, bitumen as the intermediate products was referenced to the characteristics of the pyrolosis. The result showed that bitumen first output at the pyrolosis temperature of $280^{\circ} \mathrm{C}$ and peaked at $340{ }^{\circ} \mathrm{C}$. TGA analysis result of oil shale and bitumen showed that the temperature of bitumen pyrolosis was lower than the oil shale kerogen. The pyrolosis gas of Longkou oil shale could be used to in the production of LNG and LPG.
\end{abstract}

\section{Introduction}

Oil shale is defined as a sedimentary rock that contains solid, combustible organic matter in a mineral matrix. The organic matter, commonly called "kerogen", is largely insoluble in petroleum solvent. Shale oil is obtained by heating the shale to a temperature of about $500^{\circ} \mathrm{C}$; the pyrolysis of kerogen achieved during heating is generally called "retorting". Shale oil resembles, but is not identical with crude petroleum[1].

The world's oil shale resources are mainly distributed in the United States, China, Russia, the Congo, Brazil and other places. The world's oil shale resources convert into shale oil is 689.277 billion tons, equivalent to 5.4 times of the world's crude oil [2]. In China, the total oil shale resources and potential shale oil resources are estimated at 719.937 billion tons and 47.644 billion tons, respectively. Oil shale resources are distributed in a wide range, like Fushun, Maoming, Beipiao, Yili and other places. The oil yield of oil shale is between 3.5\%-20\%, but accounting for $45 \%$ and $32 \%$ of total oil shale resources and shale oil equivalent is lower than $5 \%$, which are not worthy to be retorted for producing shale oil[3-5].

Oil shale organic matter contains a less amount of bitumen, which is a soluble in common organic solvent. On the other hand, bitumen can also obtained from the pyrolosis of oil shale. The research on group analysis of the Fushun and Maoming oil shale bitumens extracted with chloroform shows that the bitumens are different in characterisitics from that from the kerogens pyrolysis. The average molecular weight of bitumen extracted from oil shale is about higher than 1000, it may be regarded as the broken materials form oil shale kergen, or its homologs, while the average molecular weight of paraffins and aromatics of the bitumen is less than 500, and they may be regarded as the compounds wrapped in the large molecule. In this research, bitumen is regarded as the intermediate during the pyrolosis of oil shale.

\section{Experimental section}

\section{Materials and apparatus.}

The oil shale sample came from Longkou Shandong province of China, Table 1 and Table 2 shows the ultimate analysis and proximate analysis. The oil content is $15.48 \mathrm{wt} . \%$ in dry base determined by 
the Fischer Assay. The sample was crushed to under $0.15 \mathrm{~mm}$ particle size and dried 24 hours under 105 degrees Celsius. The pyrolosis device $[6,7]$ was made up of a reactor placed in an oven to heat the sample. For each test, $30 \mathrm{~g}$ oil shale sample was loaded into the pyrolosis reactor and heated to the pyrolysis final temperature, the heating rate was $2^{\circ} \mathrm{C} / \mathrm{min}$, slow heating rate was in order to eliminate the influence of the heat transfer to the pyrolosis, then rapid cooling the reactor to stop the reaction. Bitumen was obtained from soxhlet extraction device to extraction carbocoal.

\section{Analysis methods.}

Ultimate analysis of the Longkou oil shale was studied by means of the elemental analyzer, Elementar Analysensysteme GmbH, Germany; Proximate analysis adopt GB/T 212-2001, analysis the moisture, combined water, volatiles, ash and fixed carbon; Thermogravimetric analysis in this research was performed on STA409PC TGA instrument in which the sample mass loss(TG signal), in every experiment, approximately $\pm 20 \mathrm{mg}$ of samples were heated from room temperature to $600^{\circ} \mathrm{C}$ at

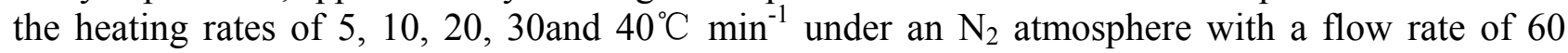
$\mathrm{mL} / \mathrm{min}$. Experiments were performed twice to ensure repeatability.

Table 1 Ultimate analysis of the Longkou oil shale $(\%)$

\begin{tabular}{cccccc}
\hline Elemental & $\mathrm{C}$ & $\mathrm{H}$ & $\mathrm{O}$ & $\mathrm{N}$ & $\mathrm{S}$ \\
\hline Content & 32.93 & 2.71 & 12.68 & 0.64 & 1.27 \\
\hline
\end{tabular}

Table 2 Proximate analysis of the Longkou oil shale $(\%)$

\begin{tabular}{cccccc}
\hline Item & moisture & $\begin{array}{c}\text { combined } \\
\text { water }\end{array}$ & volatiles & ash & $\begin{array}{c}\text { fixed } \\
\text { carbon }\end{array}$ \\
\hline Content & 1.65 & 4.28 & 32.47 & 44.30 & 17.3 \\
\hline
\end{tabular}

\section{Results and discussion}

\section{The field of pyrolosis products.}

Fig 1 shows the field of bitumen, shale oil and carbocoal in different pyrolysis final temperature. The first generation bitumen was at the temperature of $280^{\circ} \mathrm{C}$ for which content increase to the temperature at $340^{\circ} \mathrm{C}$ and then decrease, when the temperature was over $440^{\circ} \mathrm{C}$, bitumen was no longer produced. With the increase of temperature the yield of carbocoal was decreased, and it was opposite to the field of the shale oil. The adding of bitumen, shale oil and carbocoal was almost 100 percent except of gas and loss.

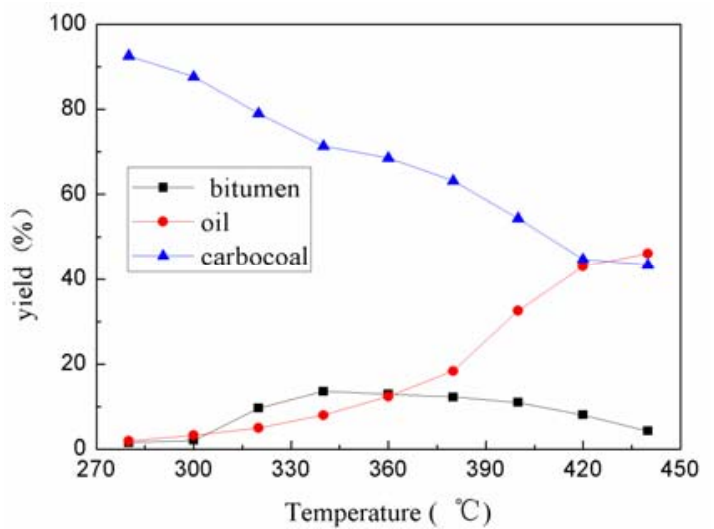

Fig.1 Final temperature vs. the field of bitumen, shale oil, carbocoal

\section{Pyrolysis of oil shale and bitumen.}

Fig. 2 shows the weight loss rate of the oil shale samples with respect to temperature during TGA in different heating rates. For TGA, total weight loss includ conversions such as water loss, hydrocarbon generation, and mineral decomposition[8]. Weight loss of 10-30\% occurred between 420 and $480^{\circ} \mathrm{C}$ for TGA experiments. And the weight loss had reached $36 \%$ in TGA experiments at $560^{\circ} \mathrm{C}$. With the speeding up of the heating rates, the curve of the oil shale pyrolosis moved to the high temperature. 
The result of TGA analysis for bitumen pyrolysis weight loss rate at different reaction final temperature $340^{\circ} \mathrm{C}, 360^{\circ} \mathrm{C}$ and $380^{\circ} \mathrm{C}$ shows that the weight loss of $10-98 \%$ occurred between 300 and $460^{\circ} \mathrm{C}$ for TGA experiments. With the improvement of the reaction terminal temperature, more content of heavy component was in bitumen, the curve of the oil shale pyrolosis moved to the high temperature with the higher reaction final temperature. Because of the bitumens are different in construction features from the oil shale kerogen, there is more light content in bitumen, the temperature of pyrolosis is lower than the kerogen.
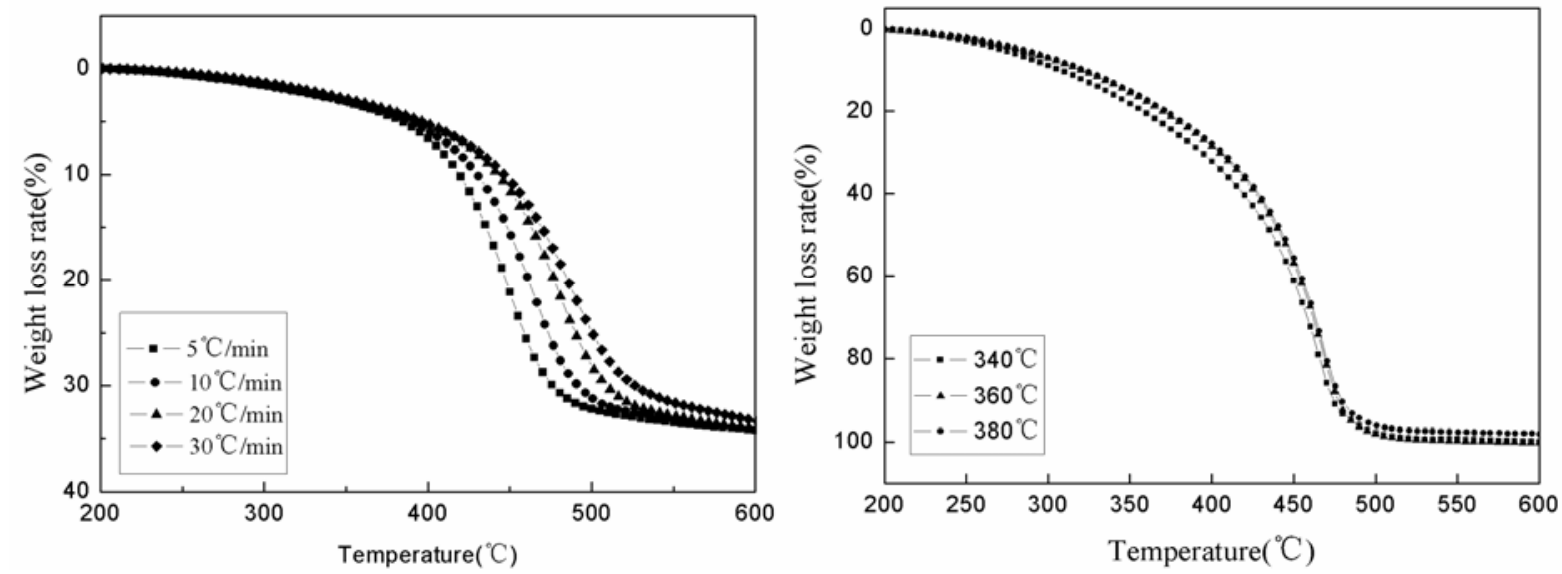

Fig. 2 Weight loss rate vs. temperature for bitumen samples using TGA.

\section{Analysis of pyrolysis gas composition.}

Fig. 3 shows the pyrolosis gas composition in the reaction temperature of $460^{\circ} \mathrm{C}$, because of the geological age of oil shale is young, so nearly $38.8 \%$ of the pyrolosis gas is $\mathrm{CO}_{2}$. Moreover, the content of $\mathrm{H}_{2} \mathrm{CO}, \mathrm{CH}_{4}$ and $\mathrm{C}_{2} \mathrm{H}_{6}$ are $22.48 \%, 10.69 \%$ and 7.53 , respectively. The calorific value of the Longkou oil shale pyrolosisi gas is $617 \mathrm{~kJ} / \mathrm{mol}$, so the pyrolosis gas can be used in the production of liquefied natural gas (LNG) and liquefied petroleum gas(LPG).

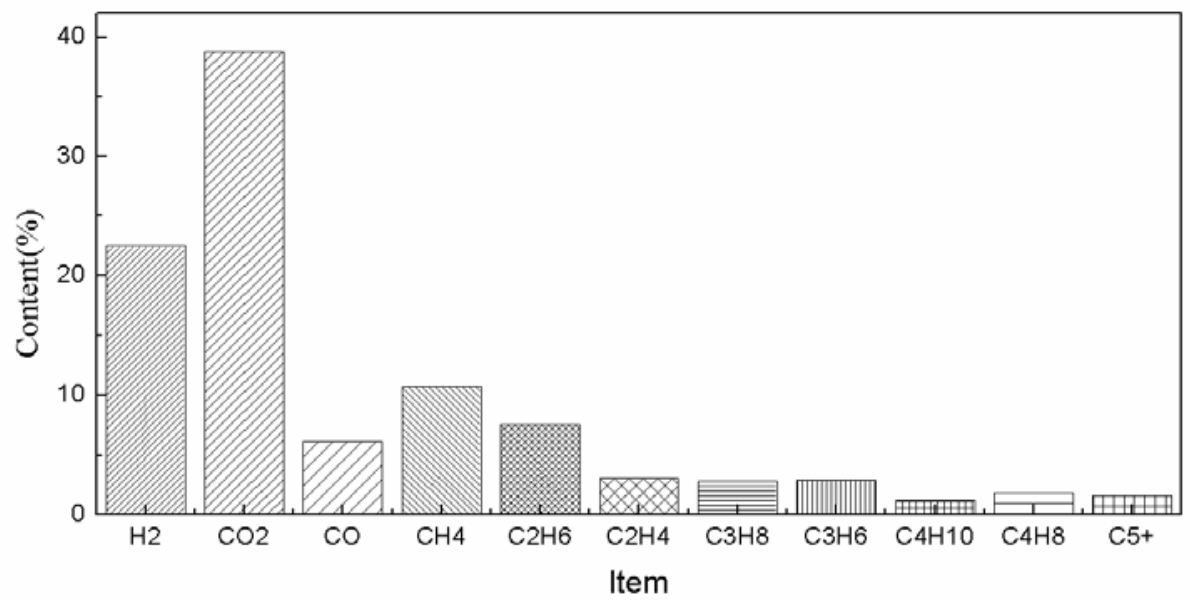

Fig.3 The content of pyrolosis gas composition

\section{Conclusion}

In order to get the intermediate products of the oil shale pyrolosis-bitumen, rapid cooling reaction equipment was used to stop the reaction, then using soxhlet extraction device to extraction carbocoal. The result of the experience is the first generation bitumen was at the temperature of $280^{\circ} \mathrm{C}$ for which content increase to the temperature at $340^{\circ} \mathrm{C}$ and then decrease, bitumen was no longer produced when the temperature was over $440^{\circ} \mathrm{C}$. The experiment get the relationship between the final temperature and the field of oil, carbcoal and bitumen. The interval of pyrolosis temperature of oil shale was $420^{\circ} \mathrm{C}-550^{\circ} \mathrm{C}$ and the bitumen was $300^{\circ} \mathrm{C}-460^{\circ} \mathrm{C}$. Compare the weight loss of the oil shale and bitumen through TGA showed that the temperature of bitumen pyrolosis is lower than oil 
shale. Over $90 \%$ of the composition of pyrolosis gas are $\mathrm{CO} 2, \mathrm{H} 2, \mathrm{CO}, \mathrm{CH} 4$ and $\mathrm{C} 2 \mathrm{H} 6$, the pyrolosis gas of Longkou oil shale can be used to in the production of LNG and LPG.

\section{Acknowledgment}

This project was funded by pecial projects of Taishan scholar construction work (ts20120518), China university of petroleum (Beijing) scientific research fund (2462015YJRC002) and national basic research program of china (973 programs) (2014CB744302).

\section{References}

[1]. Jialin Qian, Liang Yin. Oil Shale-Petroleum Alternative. China Petrochemical, 2010, 1-15.

[2]. Maocheng Li. The latest progress of world oil shale development technology. China Petroleum and Chemical Standard and Quality. 2(2014), 164-165.

[3]. Junjun You, Songqing Ye, Zhaojun Liu, et al. Comprehensive development and utilization of oil shale. Global geology. 23(2004), 3, 261-265.

[4]. Hong qin, Yaokui Yue, Hongpeng Liu, et al. Current status and prospect of oil shale retorting technologies in China. Chemical industry and engineering progress. 34(2015), 5, 1191-1198.

[5]. Lianke Sun, Senlin Li, Pengze Li. Oil shale processing technology in China and its perspective. 44(2014), 5, 35-38.

[6]. Wei Wang, Shuyuan Li, Linyue Li, et al. Pyrolosis kinetics of north-korean oil shale. Oil shale, 31(2014), 3, 250-265.

[7]. Canel, M. and Missal, P.. Extraction of solid fuels with sub-and supercritical water. Fuel, 73(1994), 1776-1780.

[8]. Hui Han, Ning-ning Zhong, Cai-xia Huang, et al. Pyrolysis kinetics of oil shale from northeast China: Implications from thermogravimetric and Rock-Eval experiments. Fuel, 159 (2015), 776-783. 